Karadeniz Uluslararası Bilimsel Dergi

Volume: 46, Summer-2020, p. (338-353)

ISSN: 1308-6200 DOI: https://doi.org/10.17498/kdeniz.722794

Research Article

Received: April 18, 2020 | Accepted: May 31, 2020

This article was checked by intihal.net.

\title{
POSTMODERN ROMAN VE YENI DÜNYA TASARIMI
}

POSTMODERN NOVEL AND THE NEW WORLD DESIGN

ПОСТМОДЕРНИСТСКИЙ РОМАН И ДИЗАИН НОВОГО МИРА

Vedi AŞKAROĞLU*

\section{ÖZ}

Romanla ilgili genel bakış açısı, onun hayatın birçok yönünü kurgusal bir biçimde yansıttığı yönündedir. Olay örgüsü olasılık sınırları içindeki insan eylem ve davranışlarını yansıtırken, kişiler toplumun içinden kimi zaman sıradan kimi zaman marjinal tipler ya da bir sınıfi, topluluğu temsil edebilecek kişiler olarak kurgulanmıştır. Zaman ve mekan kullanımı gerçeklik ve inandırıcılık açısından ön plana alınarak kişiler ve olay örgüsüyle koşut biçimde sunulmuştur. Öte yandan, romanın değişen toplumsal, kültürel, siyasi, ekonomik değer ve algılara bağlı olarak yeni bir biçime girdiğini ve toplumsal değişimin bir parçası haline geldiğini de görmek gerekir. Bu açıdan değerlendirildiğinde, günümüze damgasını vuran postmodern romanın iki boyutlu özelliklerle üretildiği ortaya çıkar. Bunlardan ilki, geçmişin sanatsal kurgu mirasının tümünü kullanması, diğeri ise tüm geçmiş geleneklerin yıkımını da sağlamaya yönelik bir çaba içine girmesidir. Öncül edebi akımların teknik özelliklerinin yanı sıra, içerik olarak da onların mirasından yararlanır. Sadece roman türünü kullanmakla kalmaz, efsanelerden, masallara, şiirden, tiyatroya, meddahlıktan gezi yazılarına kadar her türlü üretimin ortaya koyduğu düşünce, imge, anlatı, dil, üslup gibi niteliklerini birer malzeme olarak harmanlar. Bu harmanlama, günümüz dünyasının kültürel ve siyasi yapısının belirlediği tüketime dayanan, rekabetçi, küreselleşen, giderek homojenleşen yapısına eşlik edecek biçimde yapılır. Romanın işlediği malzeme sınırsızdır ve onu işleme biçimi de herhangi bir kurala, ilkeye, akıma göre kısıtlanmamıştır.

Bu makalede, postmodern roman zaman, mekan, kişiler, olay örgüsü gibi kavramlar etrafında dil, üslup, gerçeklik, yazar ve okur bağlamında öncül roman biçimleri ile karşılaştırmalı olarak irdelenmektedir.

Anahtar Sözcükler: Postmodern Roman, Üslup, Kurgulama, Gerçeklik, Yeni Toplum

\section{ABSTRACT}

The general view of the novel is that it reflects many aspects of life in a fictional way. While the plot reflects human actions and behaviors within the boundaries of probability, individuals are constructed from within the society, sometimes as ordinary, sometimes as

\footnotetext{
* ORCID: 0000-0002-7060-4139, Doç. Dr., Giresun Üniversitesi, Fen Edebiyat Fakültesi, İngiliz Dili ve Edebiyatı Bölümü, vaskaroglu@gmail.com
} 


\section{Postmodern Roman ve Yeni Dünya Tasarımı}

marginal types, or as individuals who can represent a class or community. The use of time and space is brought to the forefront in terms of reality and credibility, and presented in parallel with the people and the plot. On the other hand, it is necessary to see that the novel has entered a new form and become a part of social transformation depending on changing social, cultural, political, economic values and perceptions. When evaluated from this point of view, it is revealed that the postmodern novel, which has left its mark on the present day, is produced with two-dimensional features. The first is that it uses all of the artistic fiction heritage, and the other is an effort to ensure the destruction of all past traditions. In addition to technical features of previous literary genres, potmodern novel makes use of their content. It uses not only the novel genre but it also exploits all the materials such as ideas, images, narratives, language and style developed by previous literary works which range from legends to tales, poetry, theatre, puppet shows and even travel writing. This comprehensive blending of genres is accomplished in line with the homogenous, globalised, consumerist structure of today's world, designed by the new political and cultural policies. The material exploited by the novelists is limitless, and the way they construct their fiction is not restricted by any rules, principles or the dictations of any movement.

In this article, postmodern novel is comparatively discussed with previous novel styles in terms of time, setting, characters and plot with a view to language, style, reality, reader and author.

Key Words: Postmodern Novel, Style, Fictionalisation, Reality, New World

\section{АННОТАЦИЯ}

Понятие романа такое, что в нём отражаются многие аспекты жизни вымышленным образом. Сюжет отражает действия и поведение человека в пределах вероятности. Люди могут представлять обычные или иногда маргинальные типы или класс внутри самого общества. Использование времени и пространства является приоритетным с точки зрения реальности и достоверности. Он представлен параллельно с отдельными лицами и сюжетом. С другой стороны, роман приобрел новую форму в зависимости от изменения социальных, культурных, политических, экономических ценностей и представлений. Роман стал частью социальных изменений. При оценке с этой точки зрения выясняется, что постмодернистский роман, который оставил свой след в настоящее время, создан с двумерными чертами. Во- первых, в нём используется всё художественное наследие прошлого. Другой заключается в том, чтобы приложить усилия для уничтожения всех прошлых традиций.

В нижесдедующей статье постмодернистский роман обсуждается вокруг таких понятий, как время, место, люди, сюжет. В контексте языка, стиля, реальности, писателя и читателя оно изучалось в сравнении с ранними формами романа.

Ключевые слова: постмодернистский роман, стиль, редактирование, реальность, новое общество

Hayatın kurmaca olarak ifadesi kendini romanda bulur. İnsanı, toplumu, doğayı ve aralarındaki ilişkiyi göstermek adına, varlığını olay örgüsüne / öyküye / hikayeye dayandıran roman, hayatla ve toplumla bağlantısını her zaman kurma amacını taşımıştır. Değişen toplumsal olaylar, kavramlar ve bakış açılarına koşut şekilde, farklı kurgulama ve içeriğe sahip olmuştur. Toplumun aynası gibi görüldüğü dönemler olduğu kadar, romana öğretici, yansıtıcı ve yaşamı kurucu işlevler de yüklenmiştir. Kimi zaman da toplumun sorunlarını bırakarak, bireyin iç dünyasına yönelmiştir. Anlatıcının konumu, anlatım teknikleri, dil ve üslup da süreç içinde 


\section{Vedi AŞKAROĞLU}

deneyimlenen değişime göre yeniden şekillenmiştir. Roman akımları, kurgulama açısından kullanılan tekniklerle içerik, yaşam, insan, toplum ve ideolojinin ilişkilerine yönelik ifade biçimleri olmuştur. Romanın biçimsel / içeriksel gelişimi, gerçekliği temsil etmenin yeni yollarını keşfetmekle bağlantılıdır. Geleneksel temsil biçimlerinin alternatiflerini aramak, bir bakıma, alışılagelen, kalıplaşmış kurgu tekniklerinin geçersiz kılınması ile mümkün olur.

Postmodern romancilar da temsildeki kaçınılmaz çarpıtmanın, değiştirmenin, yeniden kurgulamanın önemini vurgulamak için, farklı bağlamlar yaratma yoluyla, pek çok yöntem ve biçim dener. Dünya her zaman değişir, ama gerçeklik geleneksel kurgularda durağan bir olgu olarak sunulur ve insanın değişmeyen doğası olduğu varsayımına dayanarak olguların evrensel, bilimsel gerçeği değiştiremeyeceği öne sürülür. Bu değişmezlik insanların zihinlerinde bilgi ile özdeşleşir ve bilginin sunduğu rahatlatıcı bir atmosfer oluşturulur. Peki gerçeklik nedir? Bilgimiz değişmez evrensel bir kural mıdır? İnsanın doğası ne derecede gerçeklik tanımı ve bilgi ile örtüşmektedir? İnsanların kurguladığından, betimlediğinden, sunduğundan ve öğretilen şekilde algılanması gerektiğinden daha farklı bir gerçeklik olamaz mı? Postmodern düşünce, bilgi, doğru ve hakikati insanın zihninde dilsel, görsel imgelerin yarattığı etki şeklinde görür: "Hepimiz bir imgeler evreni olarak tanımlanan bir üstgerçeklik tuzağına düşmüştük. Her nesne, her imge yalnızca söylensel boyutların ikincil ya da daha üst dereceli gösterge işlevleri olarak işliyordu. Şimdi, artık insanları ve nesneleri nasıl nitelendirdiğimiz nesnelerin kendilerinden ve onların işlevsel düzanlamlarından daha önemlidir. Bu idealist dünya içerisinde medyanın durmaksızın ürettiği imgelerle besleniyoruz" (Gottdiener, 2005:43). Gerçeklik artık bireye indirgenen ve çeşitli postmodern iletişim araçla zihne aktarılan bir olguya dönüşür.

Postmodernizm temsiliyet sorununa eğilir ve gerçeklik denen olgunun anlamını, nasıl kurulduğunu ve farklı olasılıkları sorunsallaştırır ve sorgular. J. F. Lyotard "her türden temsilin kendisini geçerli kllması için anlatılara / anlatıma dayandı̆̆ını, her türlü bilginin mutlak şekilde anlatı olduğunu ve araç ne olursa olsun kendilerini açıklamak, doğrulamak ve geçerli olmak için tüm sanatsal ve kültürel temsillerin üstanlatılara / üstkurmacalara gereksinimi olduğunu" (1984:7) iddia eder. Gerçeklikle onun algılanması arasında ayırt edici kesin bir çizgi çizer. Temsil biçimleri ile anlatıların ilişkisi hakkında sürekli değişen bir bilinç ortaya çıkar. Frederic Jameson bu bilinci onsekizinci yüzyıl ile günümüz arasında gösterge'nin (sign) tarihini anlatarak ifade eder. Göstergenin gerçekliği modern zamanlarda gösterge ile gösterilen arasındaki organik yorumsal bağlantıya ve oradan da günümüzde "postmodernizm dediğimiz gösterenlerin serbest oyununa" (1999:222) kadar irdelenir. Göstergenin serüveni gösteren-gösterilen ve gösterim ilişkisinin yansıtıcısı olarak roman türünü önemli kılar, çünkü roman temsil sorununun çok açık gözlenebileceği bir sanat türüdür. Hatta romanın sırf gerçekliği yansıtma iddiası ile manzum türlere karşı bir alternatif olarak ortaya çıktığını ve geliştiğini söylemek yanlış olmayacaktır.

Postmodernizm ile ilgili tartışmaların genellikle anlatılar üzerine yoğunlaşması, roman ile postmodernizm arasında, özellikle biçimsel ve içeriksel 


\section{Postmodern Roman ve Yeni Dünya Tasarımı}

açıdan, bir bağlantının kurulmasını ve tartışmanın bunların üzerinden yapılabilmesini kolaylaştırır. Romandaki biçimsel değişimler postmodern deneycilik ilkesi ile örtüşür: "Anlatım biçimi, kodlanmış ideolojiye karşılık gelen özel biçimsel ögeleri yansitmaktadır"(Gottdiener, 2005:51). Hem roman hem de postmodern söylemin çözümlenmesi; bazı değerlere, kavramlara, düşüncelere ve biçimlere karşı çıkılması ve onların ters yüz edilmesi; temsil sorununun tartışılması ve yeni biçimlerinin geliştirilmesi; gerçekçi, doğru, evrensel gibi etiketleri taşıdığını iddia eden anlatıların geçersizleştirilmesi, hem romanın hem de postmodernizmin sorunlarıdır.

Geçersizleştirme / algı kırma açısından, geleneksel anlatılarla bağlantının sürdürülmesi zorunludur. Romanın genel gelişim evresinde postmodern anlatılara dönüşmesi ya da postmodern romanın ortaya çıkışı postmodernizmin yeni türü olarak değil, gerçekliği temsil etme iddiasındaki bir edebi türün yeni arayışının biçimsel ve içeriksel bir sonucudur. Postmodernizm otantikliğin düşmanıdır ve "her türden kültürel formun üstüne çullanıp anlamlarını slyırmak ve ortada bir tür yeni imaj ya da boyut olarak bağlamsallaştırılmamış ve kolaylıkla idare edilebilir gösterenler bırakmak amaçlarını taşır" (Gottdiener, 2005:339). Geleneksel olanı geleneksel olanla yıkmak mümkün olabilir. Yeni söylemler ve bağlamlar kurgulayarak, eski metinleri, anlatıları, olayları ve temsiliyeti kullanarak kırmak olasıdır. Kurgulayarak gerçekliğin nasıl insan yapımı olduğu ve bu yüzden gerçekliği temsil edemeyeceği, kurguyu manipüle ederek yakalama imkanı doğar ve postmodernizmin genel anlamda yaptığı budur.

Başlangicından beri roman diğer edebi türlere karşı bir tepkiyi içinde barındırır ve bu yüzden de pek çok söylemin işlenmesine uygun bir türdür. Diğer temsil biçimlerini içine alarak onları sorgulama ve eleştirme imkanını içinde barındırır. Örneğin, realist roman, gerçeğe yakın, olabilecek durumları, doğaya, insana ve olasılık ilkelerine bağlı kaldığını iddia eder ve iddiasını sürdürmek için nedensellik ilişkisini kullanır. Gerçekçi romanı bir "paradigma olarak düşünmemek ve romanın genel özelliğini kendini yansitma ve kurma geleneği olarak kabul etmek gerekir" (Hutcheon, 1984:38). Roman yenilikçidir ve hem edebi hem de edebiyat dış1 unsurların kültürel kodlarını ve ifade biçimlerini içererek, bunları karşılıklı bir etkileşime tabi tutar. Her roman "benzersiz bir değişsenler kümesidir" (Bradbury, 1977:289), çünkü pek çok olasılığın, dil kullanımının, anlatım tekniğinin, farklı söylemlerin ve seçimlerin yapılabildiği ve bunlara bağlı olarak, farklı etkilerin yaratılabildiği bir sanatsal üretimevidir. Bu üretimevi, istenen türden algının oluşturulmasını mümkün kılar, çünkü sadece kurgu değil, kurgu yoluyla gerçeklik üretilebilen bir yerdir.

Roman, gerçekçi olma iddiasında, geleneksel bazı öğeleri kullanırken, bu iddiasını mantıklı ve geçerli kılmak adına edebi olmayan bazı araçlardan alıntı yapabilir ve bunları birleştirerek yeni bağlamlarda sunabilir. Postmodern romanın çağın teknolojik olgularından ve diğer sanat dallarının gelişiminden etkilenmemesi de düşünülemez. Sinema, televizyon, internet gibi, her an sınırsız görsel imgeyi insanların zihinlerine sokan bir görsel çağda, romanın görsel öğelere artık gereksinimi ve belki de bu araçlar kadar yeteneği de kalmamış olabilir. Bu yüzden 
temsil ettiği nesneyi, kişileri ve değerleri görsel bir öğeden çok imge yağmuru şeklinde bir gerçeklik olarak sunar. Başka bir deyişle, zaten farklı temsillerin aracı olan roman, görselliğe dayalı temsilleri daha iyi sunabilen türlerin yaptığını yapmaktansa, kendine özgü yeni temsil biçimleri bulma yoluna gitmiştir.

Ontolojik düzeyde yaşanan gerçekliğin ve insan doğasının sadece olasılıklar üzerinden kurgulanarak sunumunun sorgulanması, belki de postmodern romanın ana çıkış noktasıdır. Sadece gerçeklik kavramı değil, sunum ve aktarım aracı da sorgulanır. Roman bir aracıdır, araçtır ve kurgusal doğası gereği algıyı çarpıtır, bozar ve yeni biçimlere sokar, çünkü "Bir "yapı" olarak her edebi metin, köken ve erekten yoksundur; işleyişi yazar bilinci ya da bir türün kurallart ya da bir geleneğin hatları tarafindan belirlenmemiştir. Her edebi metin, farklı bağlamlara ve okurlarının farklı kimlik ve ilgilerine göre pek çok okumaya açıtır" (Lucy, 2003:343). Yazar sadece bir bireydir ve bu yüzden özneldir. Kurgu sadece olasılıktır ve tümel / genel değildir. Roman dile dayanır ve bu yüzden gösteren ile gösterilen arasındaki ilişki ortak görüşe dayanmaz. Kültürel belirlenmişlik / yerleşik algı, postmodern romanda çürütülmek istenen bir olgudur. Dilin göstergesel özelliği, her ne kadar sunulan nesneler, yollar, mobilyalar, arabalar, evler, betimlenen kırlar, insanlar gibi nesnesel öğeleri gösterse de, bunların arasındaki ilişki ve etkileşim, ne olduğu bittiği ve olay örgüsü tanık gerektirir ve bu tanığın öznel görüşünün içine sinen bir bakış açısı vardır. Bakış açısının yanı sıra, anlatıcının sesi, yazı üslubu ve nesne olan kitap gibi gerçeklikten dereceli uzaklaşmayı imleyen aracılar bulunur.

Gösterenle gösterilen arasına birkaç katmanlık açıklık ve mesafe girer ve karşılıklı konuşmada kullanılan sözcüklerin göstergesel anlam inşasının sorgulandıği bir yerde, bu denli mesafeli gösterimsel ilişki gerçekliği yansıtamaz. Gösterge "bir yalan"dır; "başka bir şeyin yerine duran bir şeydir" (Gottdiener, 2005:15). Aynı şekilde "Gösterilen (de) bir yalandır; tam sahteliğini gösterdiği anda olabiliri ortaya çıkaracak bir gerçeğe-benzerliğin alanını çizer" (Barthes, 2009:33). Pek çok postmodern anlatı, içine anlatımın göstergesel rolü ile ilgili aracılık sorununu dahil eder. Yazar bir gösterileni nasıl gösterebilir ve gösteren nasıl bir gösterim işlevini sağlayabilir gibi sorular yanıt bulmak zorunda kalır. Roman, temsiliyet sorunsalına eğilir ve metnin ötesindeki bir dünyaya yönelerek, ancak başka metinlere ve olgulara göndermeler yoluyla gösterim işlevinin yerine getirilebileceğini iddia eder. Gerçekçi roman, kendi gerçekliği konusunda okuyucuyu ikna etme çabasında, "aynı kültürün edebi olmayan öğeleri ile benzer bir deneyimin betimlenmesi yoluyla deneyimin temsilini sağlar" (Lodge, 1977:25). Postmodern roman ise, daha önceki betimlenmiş deneyimlerin betimlenmesi, onlarla ilişki kurulması yoluyla kendini var eder. Yeni göstergeleri, metinleri ve bilgileri yeniden tasarlamak adına işe koyulur.

Göze hitap eden bir filmin ya da oyunun, konuşmalar ve ses yoluyla, izleyicinin duyularına bıraktığı somut ve daha nesnel etki, gerçeklik algısı yaratma konusunda romanın benzer etkilerine göre daha ileri bir seviyededir. Ancak, bu sanatlarda, izleyicinin düşünce, duygu, hayal etme, hissetme gibi soyut yetileri sınırlandırılmış olur. Alg1 sadece görme, duyma, dokunma, koklama ile nesnenin boyutunu, dokusunu, yapısını, rengini veya sertliğini anlamaktan ibaret değildir. 


\section{Postmodern Roman ve Yeni Dünya Tasarımı}

İnsan aynı zamanda nesne ötesi bir varlıktır ve sadece nesneye dair dışsal algıyla yetinmesi imkansızdır. Tiyatronun ya da filmin çizdiği gerçeklik, tek boyutlu olduğundan, romanın sunduğu gerçeklikten daha özneldir. Bu yüzden, postmodern romanın metinsel özellikleri çok önemli hale gelir. Postmodern metinle gerçeklik arasında karmaşık bir ilişki olduğu akılda tutulmalıdır ve sırf bu özelliği ile diğer postmodern sanat biçimlerinden farklı değerlendirilmelidir.

Metne dayalı bir gerçeklik imkansızdır. Dilin aracılığı, anlatıcının varlığı, anlatının içine yerleştiği biçim ve anlatımın kendisi, gerçekliği temsil ettiği nesneden ve değerlerden uzaklaştırır. Romanda anlatıcıyı gizleme çabalarına rağmen, ancak bir seviye daha ileride bir gerçeklik kurulabilir, çünkü anlatıcının ve anlatının kendisi, günlük hayatta yapılan kişiler arasındaki karşılıklı konuşmaya ya da tek bir kişinin kendi içinde akıp giden düşünceye benzerdir. Yazar / anlatıcı olup bitenin farkındadır, gözlemler yapar ve değerlendirmelerde bulunur. Zaten dünya tek başına algılanabilen bir alan değil, gözlem yapan bir zihnin süzgecinden geçerek anlaşılan bir olgudur. Zihin de dil yolu ile gerçek olanı kavramsal çözümlemeye tabi tutarak, eylemi işleyen özneyi, etkilenen nesneyi, eylemin gerçekleştirildiği yeri ve zamanı algılar. Roman da aynı şekilde zihne gerçek dünyanın sunduğu malzemelerin bir kısmını sunar ve gerçeklik, öznel de olsa, bu malzemelerin zihnin süzgecinden geçirilmesi sayesinde kavranılabilir hale gelir.

Roman her gözlemciye göre değişen ve nesnel gerçekliğin kurulamayacağını belirleyen öznelliği ile farklı arayışların içerildiği bir metinsel araçtır. Anlatılar "edebi temsilin zayıflamış bir hali" (Genette, 1982:130) değildir, daha ziyade tiyatrodan daha iyi taklit özelliğine sahiptir, çünkü anlatıcı vasıtasıyla, süzgeçten geçirilen ve aktarılan bakış açıları sunarlar. Roman yazarın belirlediği bir göstergeye dönüşür ve gösterilen - gösteren ilişkisi kurar. İlişkinin nedensizliği, ancak okurun ortak alg1, duygu ve düşünceye yaklaşması ile ortadan kalkar ve gösteren zamanla pek çok okur için aynı gösterilene karş11ık gelebilir. Postmodern roman göstergesel ilişskiyi yıkmak ve sürekli değişen bir gösteren-gösterilen ilişkisi yaratarak, gösterimin ve gerçekliği temsilin geçersizleştirilmesinin arayışı gibi durmaktadır. Biçimle biçimin parçalanması, teknikle tekniğin kırılması, yapıyla yapının bozulması arasında sürekli evrilen bir çizgiselliğe sahiptir. Postmodern romanda "her an değişen vurgulara, yeniden kurgulamalara yönelim vardır ve bu gerçekliğin uyarlanmasl, katlanilabilir hale getirilmesi ve ayn zamanda genel modern deneyimin kirılması" (Stevenson, 1992:15) işlevini görür.

Hayat devingendir, değişim süreklidir ve bu yüzden her yeni koşul ve durum yeni bir algıyı gerekli kılar. Postmodern romanın da iddiası değişimin gerektirdiği değişken, sürekli yenilenen ve bu yüzden homojenliği asla sağlanamayan bir algının gerçekliğini okura ve yeni dünya insanına kabul ettirmektir. Modern romanın kapalı biçimine ve bütüncül, ortak, evrensel gerçeklik önermelerine karşın, postmodern roman açık uçlu ve çoklu gerçeklik sunumu ile kendini ortaya koyar. Her bir önerme, en az diğerleri kadar değerlidir ve metnin kesin bir çizgisi bulunmaz. Sürekli bir değişkenlik, sınırsız bağlamlar ve söylemler içinde bir olayın her tarafının görünmesini sağlamaya yönelik bir çaba mevcuttur. Her bir önerme bir diğerinin değilidir ve bu yüzden hiçbir önermenin tek başına gerçekliği yansıtma yeterliliği 
olamaz. Gerçeklik değişkenliktir ya da tüm önermelerin toplamıdır ve birbirinin inkarını sağlayan bağlamların bağlam dış1lı̆̆dır: "Herhangi bir şeyin kesin olduğuna dair herhangi bir kesinliğin olmadiğ yerde edebi ya da felsefi kararlar vermek nasil mümkün olabilir ki?" (Lucy, 2003:208). Postmodernizmin modern romana yönelik yaptığı "sahte gerçeklikler kurma" suçlamasının aynısı, postmodern roman ve sanat için de yapılabilir. Eğer gerçeklik kurulamaz ve sadece bireye özgü ise, modernist romanın bunu yaptığını iddia etmek kendi kendini çürüten bir mantığı içinde barındırır. Daha doğru yaklaşım, iddialardan öte, her iki roman anlayışının, kendi yaşama tasarımlarına ve ideolojilerine uygun olanı önerdiğini ve içeriğe taşıdığını söylemektir.

Hutcheon, postmodernist romanın "geleneksel olanin, insanin zihnine bir şeyler işlemesine meydan okuyan ve hakim bakış açısının içerildiği metinlere alternatifler sunan bir tür" (1989:1-2) olduğunu anlatır. Anlatılar, dünya hakkında konuşmanın farklı yöntemlerini geliştirir ve "aşinalığı kırar" (Bakhtin, 1981:38). Postmodern roman dünya hakkında konuşma yollarının tamamen yabancılaştııılması üzerine kuruludur. Yöntemleri, içeriği, kurguyu, bağlamları, söylemleri sorgular ve alışkanlığı yerle bir ederek, sürekli soru soran bir okur kitlesi yaratmayı hedefler. Değişik sanat türlerinden ödünçlemeler yapar ve deneyci bir yaklaşım gösterir. Bakhtin, postmodern romanın, farklı zaman kavramlarından oluştuğunu ve açık uçlu şimdilik kavramının odak haline getirildiğini söyler. Açık uçluluk, destanların ve pek çok diğer edebi türün sunduğu tümlük ve tamamlanmışlık kavramlarının çöküşünü sağlar. Bitmiş, deneyimlenmiş, yaşanmış bir tarihsellik algısının yerine, sürekli şimdiki zamanda gerçekleşmeye devam eden bir zamansal çizgi, gerçekliğin sürekli oluşmasını, her an sürekli kurulduğunu ve sonuca ulaşmanın imkansızlı̆̆ını belirler. Bakhtin, romanın zamanı yeni bir kavram olarak hayata sokan bir tür olarak geliştiğini söyler: "Kesinliğe dayanan geçmiş zaman ve sinuflandırıcı mesafe romanın bir tür olarak gelişmesine katkısı olmamıştır. Roman tam da destansı mesafenin parçalandığ dönemde şekillenir. Bu zaman sanatsal temsil nesnesinin kesin olmayan, aklşkan günümüz gerçeklik seviyesine düşürüldüğ̈̈ bir zamandır" (1981:38). Günümüz gerçekliği ile doğrudan kurulan bu bağlantı ve kesin olan bir geçmiş ile bağlantının koparılması, postmodern romanı kuran şeydir. Roman, günümüz kurgu farkındalığının ve sürekli değişen şimdiki zaman algısının, kesin olmayan ve tümlenmemiş özelliğinin yansısıdır. Şimdiki zaman vurgusu, çağa uygun yapısı ile romanın özgürleşmesini sağlarken, zamanı kavramsallaştırarak artan bir şekilde izleksel yapının da sınırlarını genişletir.

Modernist romanda kullanılan malzemenin kısmi algı kırıcılığına rastlamak mümkündür. Bir bakıma gerçeküstü öğelerin kullanımı, görülemeyen, fark edilemeyen, bilinçaltı gerçekliğin rüya atmosferi içinde sunumu, modernist romanın, anlaşılmayı sağlamak adına kullandığı mitsel ya da sembolik öğelerdir. Foucault, bu öğelerin kullanımını "heterotopia" kavramılla açıklar. "Heterotopia kavramıyla Foucault "çok sayıda bölük pörçük olanaklı dünya"nın "olanaksız bir mekan"da bir arada varolmasını ya da, daha basit biçimde, ortak olarak ölçülemeyeceği halde birbiriyle üst üste ya da yan yana getirilmiş mekanları anlatır. Karakterler artık temel bir muammayı nasıl çözeceklerini ya da meydana çıkarabileceklerini 


\section{Postmodern Roman ve Yeni Dünya Tasarımı}

düşünmemekte, bunun yerine şu sorulara cevap aramaya zorlanmaktadirlar: Bu hangi dünya? Bu dünyada ne yapılmasl gerekiyor? Bunu benliklerimden hangisi yapacak?" (Harvey, 2012:64). Rüyamsı öğelerin kullanılması temsil biçimlerindeki bir arayış gibi görünmektedir, çünkü geleneksel temsil biçimleri sınırları belli, kalıplara sığdırılan, kapalı anlatımı öngörür ve gerçeklik yanılsaması diye adlandırılabilir. Yanılsama bir tür pencereye benzetilebilir. Okur sözcüklerden örülmüş bir görüntü dünyasına sıkışmış bir durumda, hapishane benzeri bir mekanda, gözlerinin önüne sözcüklerden örülen bu görüntü ile dünyayı algılamaya davet edilir. Pencereden sunulan gerçeklik sadece kısmi olabilir. Resmin tümü gösterilmez ve sadece sunulanla yetinmek zorunda kalan okur başka gerçekliklerin farkına bile varmaz. Postmodern romanın yaptığı şey ise kapalı mekanı tümüyle açmak, duvarları yıkarak gerçekliğin her açıdan görünür hale gelmesini sağlamaktır. Bir zamanlar edebiyatın romantik uzamı olan yer, "genel bir insani varolus düzlemine dönüşür; burada kimlik, köken ve hakikat gibi kavramlar, insan "varlığını" ve kültürünü anlamanın temelleri yerine, çok katll ve yapısız toplamalar olarak görünürler" (Lucy, 2003:16). Okur, modern romanın kapalı anlatımını, hiyerarşik sunumunu, kronolojik anlatım düzlemini, mekan va zamanın önemini sorgulamaya başlar ve her tarafinda gözleri olan bir varlığa dönüşerek, postmodern romanın sunduğu "yapısız toplamalar"1 görmeye, bir şeyi her açıdan algılamaya ve gerçekliği bu açılardan yeniden kurmaya doğru adım atar.

Modernist roman, postmodernist yazar için bir hazine durumundadır. Sorgulamaların kaynağını oluşturur, yeni eleştirel yaklaşımın somutlanmasını sağlar. Aynı zamanda "seç beğen al" mantığı ile yazar için malzeme deposudur. Postmodern edebiyatın yeni yönelimi "Bireycileşme, sorumsuzlaşma ve soyutlaşma" üzerine kurulur ve "Yazın bu yüzden büyük ölçüde bir haz ve oyun aract gibi algllanmaya başlandl. Özellikle son yılların popüler olan postmodern yönelimli romanlarının biçim ve biçemi, bir uçarllık ve uçuculuk yansittyor. Bu yüzden, insan toplumsal matris'in gitgide görünmez kllındiğg, yaşanan gerçekliğin geçmişe göndermeler ve geçmişten alıntılar tarafindan önemli ölçüde kamufle edildiği duygusuna kapıllyor zaman zaman" (Oktay, 2000:62). Kurgulanmış pek çok kişi, postmodern romanın malzemesi olarak yeni kişiliklere büründürülür, sözler söyletilir, farklı davranışlar sergilerken betimlenir, temsil ettiği değerlerden arındırılır veya bu değerler başka değerlere dönüştürülebilir. Kişiler, izlekler, söylemler, bağlamlar, olay örgüleri, konular da bir tür depo gibi, yeni roman yazarlarının emrine amadedir ve isteyen kişi istediği öncül metinlerden ödünçlemelerle istediği anlatıyı kurgulayabilir, çünkü artık sanatın yüceliği, sanatçının özerkliği ve eserin özgünlüğü değil, bağlamların ve söylemlerin hakimiyeti önemlidir. Bu yüzden, postmodern romanda kahramanlar yerine kukla / karikatür / alegorik figür diye tanımlanabilecek kişiler işlenir. Postmodernist roman kahramanları çoğu zaman "hangi dünyada bulunduklarını karıştırmış gibidirler ve bu dünyayla nasıl bir iliş̧ki içine girmeleri gerektiğini çıkaramazlar" (Harvey, 2012:56). Kurgusal kişilerin toplum adına hareket etmesi beklenmez. Simgesel boyutlarını kaybetmişlerdir. Temsil ettikleri bir kitle ya da değer yoktur. Genellemelerden arındırılmış bir toplum içinde, herkes sadece kendisidir ve bu 
yüzden öğretilere, ideolojilere, kültürel göndergelere sahip değildir. Aynı durum okur için de geçerlidir, çünkü okur da bir tür roman kişisidir ve onun kim olduğunu kendisi dışında kimse bilemez. Yeni okur tipi "okuduklarl romanlarda her şeyi buluyor, her şeyi birbirine dönüstürüyor, birbirleriyle bağlantılandırıyor ama bu geniş görüşlülük içinde siyasal aidiyete vurguda bulunmaktan titizlikle kaçınıyorlar" (Oktay, 2000:78). İdeolojilerden / öğrenmekten / genel çıkarımlar yapmaktan / toplumsallıktan arınmış / arındırılmış okur gibi, yazar da yeni bir şey söylemek uğraşında değildir, sadece söylenmiş olan birçok şeyden seçmeceler yaparak onları daha iyi ya da daha farklı söylemesi yeterlidir.

Romanın daha önceki türlerden alıntı yapması gerçeklik kurgusunun ve modernist bakış açısı ve değerlerinin yıkılması amacını taşıdığından, genellikle metinlerarası kurulan ilişki içinde yıkıcı etkiye sahip parodi öğesini barındırır. Postmodern roman, parodi öğesi yoluyla öncüllerinin yorumuna dönüşür, kurgusallığ 1 kurgusallık içinde yıkar ve temsil biçimlerinin, yazarın konumunun sorgulamasını yaparak alışılagelen biçimleri, değerleri kırar. Romancı artık modası geçmiş biçimlerle başarılı bir şekilde şimdiki zamanın gerçekliğini kuramaz. $\mathrm{Bu}$ gerçeklik hızla değişmekte ve her yeni nesil için bu hız artış göstermektedir: "B $u$ yüzden romancılar bu hız karşısında evrimleşmek (uydurmak, ödünçlemek, çalmak ve diğer türlerden bohça yapmak) zorundadır ki sürekli değişen gerçekliği yakalayabilsinler" (Johnson, 1973:17).

Postmodern romancı evrimleşmeyi kurma-yıkma oyunu şeklinde gerçekleştirir. Bir yandan bir bağlam ve söylem yaratır, içine olaylar ve kişiler yerleştirir ve gerçekliğin bir yansımasını sunar ama birdenbire bu kurduğu şeyi yıkar ve tekrar yeni bir gerçeklik inşasına girişir. Metinler ve alıcılar ( ya da romanlar ve okurlar) arasındaki anlam akışını kontrol eden öncül (yazar) ya da altta yatan (yapisal) bir kaynak ya da mekanizma yoktur: "Yalnizca metinsel satıhların bir oyunudur olan biten. Söylenecek -anlam yerine oyun- anlam vardır" (Lucy, 2003:41). Mantık oyunlarında olduğu gibi, yazar bir önerme ile ortaya çıarak bu önermenin doğruluğunu göstermeye, kantllarla desteklemeye ve okuru inandırmaya çalışır. Sonra ikinci bir önerme geliştirerek, ilk önermenin karşısına dikilir ve ilki için sunulan kanıtların geçersizliğini ispata çalışır. İlkinin yıkılması ile birlikte üçüncü önerme ortaya çıkar ve her bir önerme bir sonraki tarafindan çürütülür. Bir tür kısır döngü içinde, gerçekliğin gerçeksizliği vurgulanmış ve değerin değersizleştirilmesi sağlanmış olur. Postmodern yazar gerçekliğin ancak bu şekilde sağlanacağını gösterir ve modern düşüncenin öğrettiği gibi, durağan, aydınlanmacı, mantıkçı, ilerici, nesnel, geleceğe dönük bir kavram olmadığını hem kurguladığı kişileri, hem anlatısını, hem kendisini hem de okuru ve onun konumunu parodileştirerek ispata çalışır.

$\mathrm{Bu}$ çaba, "Metnin kendi için ve kendine yeterli bir gönderge düzeneği oluşturması, bu düzeneğin çözümlenmesi sürecini birlikte yürürlüğe sokan eleştirici ve meşrulaştırıcı eğilim ile metni, tüm estetik etik dĕger-yargısal içeriğinden kurtararak alılmayıcının zevkine ve değişim değerine (tiraj ve imaj) bağlayan metalaştırıcı yönelim" (Oktay, 2000:77) olarak ortaya çıkar. Ancak, yap-boz oyunu gerçekliğin geçersizliği bağlamında kendi içinde ironik bir boyut taşır. Postmodern 


\section{Postmodern Roman ve Yeni Dünya Tasarımı}

yazarın kendisini, okurunu ve eserini var etmesi ancak eskiyi, modernist olanı yıkması ile mümkün görünmektedir. Aslında yok etmeye çalıştığı biçim, içerik ve algı kendisini var eden birer değere dönüşmüş olur. Eytişimsel açıdan, modernizmin karşıtllğııı yaparak kendini var eden postmodernizm, kendisini var eden kalıcı, evrensel değerler dizgesine sahip modernizmi yıkmaya çalışarak kendi sonunu da hazırlamaya başlamış olmayacak mı? Ya da başka parodisini, ironisini, pastişini, kolajını yaptığı her öncül çalışmanın yıkımını sağlamaya çalışırken, aynı zamanda onları tekrar gün yüzüne birer değer, ideoloji, öğreti ve gerçekliğin alternatifi olarak çıkarmış olmaz mı?

Postmodern roman yazarın, yeni yazım teknikleri bakımından mevcut biçimlere dayanarak yazması neredeyse kaçınılmaz görünmektedir, çünkü gerçeklik algısı geleneksel temsil biçimleriyle sıkı bir bağ içindedir. Yenilik, yeni biçemlerin, konuların ya da izleklerin geliştirilmesi ve bu doğrultuya uygun mekan, zaman ve kişilik kurgularının oluşturulması ile değil işlenecek bakış açılarına uygun söylem ve bağlamlar oluşturma yolu ile eski kaynaklara dayalı bir kurgu oluşturma yönündedir. Postmodern yazar da günümüzün sürekli değişen kavramların temsili için dönemin yönelimlerine, biçimlerine ve deneyciliğine yaslanmak zorunluluğunu hisseder. Eğilimlerin çoğunluğu mevcut formlara atıfta bulunarak uydurmak, ödünçlemek ya da çalmak şeklinde olabilir. Bu olgu aslında postmodern romanın iddia ettiği gibi öncül anlatılardan ve tarihten bir kopuşu değil bir tür devamı niteliğindedir. Kopuş tümüyle reddi gerektirir oysa postmodern roman farklı söylemler yaratma peşindedir, ancak söylemler romanın biçiminde değişimi de getirir ve genel olarak anlatının simgesel boyutunu dikkate sunar. Yine de anlatılarda gerçeğin temsili, ya da bunların kırılması için öncül metinlere ve biçimlere dayanma zorunluluğu vardır ki kopuş yerine devamı sağlayan bu özelliktir. Diyalektik açıdan karşıtı yaratabilmek için bir merkezin, temelin, iddianın ya da verili bir gerçekliğin olması ön koşuldur. Verili / kurulu / merkezi / geçerli olan her ne ise onun bağlamını, söylemini ve biçimini değiştirerek geçersizleştirilmesi mümkün olabilir. Ancak biçimi değiştirilen olgu, metin, anlatı ya da her ne ise bir kez daha gözler önüne gelmek zorundadır. Bir şeyin yalanlanması için o yalanın bilinmesi gerekir ki o da yalanın bir kez daha söylemsel bir etki yaratması açısından firsat oluşturur.

Postmodern roman modernist romanın tersi bir söyleme sahiptir. Romanın biçimine yönelik değişen bir tavır söz konusudur ve genel anlamda anlatının temsil sorunu ön plana çıkarılır. Anlatıların nasıl oluşturulduğu ve kurgulandığının yanı sıra kurgu ile gerçeklik arasındaki ilişki günümüz romanının önemli bir konusudur. Postmodern romancılar arasında genellikle tüm temsil biçimlerinin gerçekliği yansıtmak yerine onunla ilgili algıyı çarpıttığı ve sınırlandırdığı görüşü yaygındır. Gerçeklik temsil edilemez bir şeydir ve ideolojilere göre değişen bir kurgu olarak düşünülür. Aslında gerçekliğin var olup olmadığı bile sorgulanır hale gelir. Var olanın sadece biçimler, gelenekler ve uygulamalar olduğu öne sürülür.

Yansitmacı olduğunu iddia eden edebi ve sanatsal metinlerin çokluğu ve farklılığı karşısında gerçeklik daha da belirsiz hale gelmekte ve insanların zihinlerinden uzaklaşmaktadır: "Yazın, toplumsal olarak ayrıcalıklı bir dolaşım biçimi gibi duyumsanmaz artık, hem düş, hem tehdit olarak verilmiş, yoğun, derin, 
gizlerle dolu bir dil olarak duyumsanır" (Barthes, 2009:15). Günümüzde okur artık doğrunun ya da neredeyse gerçekliğin kendisini kaybetmiş görünmektedir ve bulabildiği şey derinlik ve önemden arındırılmış parçalı kurgusal önermelerdir. Metnin gösterge niteliğinin reddi, sınırlandırma ve bilmezlik konumu modernist metnin göndergeli, göstergeli ve temsil iddiasının yerini almıştır. Metnin ya da yazarının artık bir yetkisi bulunmamakta ve metin tümüyle melezleşmiş bir biçeme dönüşerek kendi sınırlarını daraltmakta ve herhangi bir şeyin temsil edilmesi konusunda kendini inkar etmektedir. Tarihsel süreçte, "Yazı gittikçe artan bir katılaşmanın tüm durumlarından geçti; önce bir bakışın, sonra bir edimin, en sonunda bir öldürmenin konusu olduktan sonra, bugün son durumuna, yokluğa ulaşmaktadır" (Barthes, 2009:15).

Her şeyin mantıktan ve genellemeden uzaklaştırılması ile sınırsız bir oyun oynama olasılığı ortaya çıkar. Öte yandan bu sadece bir oyun olarak kalır ve gerçeklikten koparılmış, ciddiye alınması gerekmeyen, üzerinde tartışılması ya da eleştiri yapılması dahi boş olan sıradan bir metin üretimine dönüşmüş olur: "Artık gerçekliği kuramayız, sadece olası dünyalar kurgulayabiliriz" (Calinescu, 1987:203), ancak bu olası dünyalar kullanılan anlatım teknikleri ile sinırlıdır. Romanın kurduğu, geleneksel dünyalar olabilir, olası dünyalar değil, çünkü olasıllığı ortaya çıkaran şey gelenek ve uzlaşımdır. Günümüz metinlerinde ise uzlaşımın olasızlığı ortaya konularak, parçalanmış bir dünya algısı yaratılır. Uzlaşım, çelişkili bir şekilde, ya hiç yoktur ya da olsa bile istemeden kabul edilmek zorunda kalınan bir kavramdır. Metinlerin sundukları imgelerle, dil öğeleri ve yarattıkları söylem ve bağlamlarla kişiye göre değişen bir algı yarattıkları kabul edilmektedir. Ancak dilin insanlar arasında bir işteşlik görevinden çok karşı1ıklı diyaloğu, anlaşmayı, ortak bir dünya algısını kıran, yok edici, parçalayıcı, toplumsal ve genel olana düşman bir işlevi olduğunu söylemek bir kaosa işaret eder. Eğer gerçekten tüm "anlam, bilgi ve değerler, aslında paralel dil-oyunlartyla sinırlı" ise o zaman elbette dünyay1 değiştirmek için hiçbir umut yoktur. Şu ya da bu "dil-oyunu değişebilir, ancak "dünya" asla değişemez: Çünkü herhangi bir "dünya" nosyonu belirli bir diloyununun içinde kilitlidir" (Lucy, 2003:123). O zaman akla hemen şu soru gelmelidir: toplumsal bütünlüğe yönelik bu kadar tehlikeli bir işlevi olan dilin ortadan kaldırılması gerekmez mi? İnsanlar birbirlerinden ayrılmak, farklılaşmak, birbirlerini öteki konumuna sokmak ya da toplumsal yaşamda tek kalmak, kendileri olmak için mi dili kullanmaktadır? Edebiyat neden dili kullanır? Edebiyatın ana hedefi toplumsal uzlaşıyı dil vasıtası ile yok etmek midir? Neden şiir, öykü ya da roman yazılır? Edebiyat artık gerekli midir?

Roman, diğer sanatsal alanlar gibi, mevcut yaşantıya karşı seçenekler sunar. $\mathrm{Bu}$ yolla, farklı olasılıklar, farklı gerçeklikler ve farklı bir dünya seçenekleri oluşur. Seçeneklerin doğru olması önemli değildir. Günümüz romanının asıl uğraşısı da budur. Pek çok romanc1, günümüzde, ya daha eski metinlere dönüş yaparak ya da olmayan metinleri varmış gibi göstererek romanlarını kurgular. Borges, ikinci durum için şunu söyler: "bu tür metinlerin varlı̆ı̆ı kabul etmiş görünmek daha iyi bir yöntemdir" (1985:12), çünkü kendisine dönülen metin, gerçekten de yazılmış bir metinden daha az doğru ya da geçerli değildir. Dilin insanlar arasında nasıl bir etki 


\section{Postmodern Roman ve Yeni Dünya Tasarımı}

oluşturacağı, okurun tek ve yalnız kalacağı, toplumdan ayrıksanacağı, toplumsal uzlaşının var olup olamayacağı, şiir ya da roman yazmanın ne tür sonuçlar doğuracağı postmodern çağda artık önemsenmez. Postmodern tüketim toplumunun ana özelliğini belirleyen şey, kitabın kaç baskı yapacağı ve yazarı ile yayınevine ne kadar kar getireceğidir. Oktay, "Postmodern yapıtlardaki o bitmez tükenmez alıntıların (metinler ve resimler bağlamında) düşünsel gerilim yaratmaktan çok, tüketim ideolojisinden beslenen bir kültürel hedonizmi klşkırtmaya yardımcı olduğunu" (2000:10) düşünür. Kısacas1, içeriğin üstün değerler, gelişkin kişiler, gerçekçi betimlemeler, sosyal çözümler vb konulardan oluşması gerekli değildir. İnsanlar artık yeni dünyalar yaratabilir ve "bu da dil ve söylemin doğası sayesinde mümkün olmaktadır" (Borges, 1985:14). Aynı dil ve söylem, postmodern romanda dünyayı yeni bir düzene sokan ve böylece dünyayı kuran bir dil oyunudur. Postmodern romanı da dil ve söylem araçlarını kullanarak, olay örgüsü, betimlemeler, gerçekliğin sunumu, kişilik geliştirilmesi, ahlaki öğretilerde bulunması gibi kaygılar yerine, sadece bir tür yaratıcı oyun oynamak olarak görmek mümkündür.

Gösterenleri ve kuralları keyfi olan dilin, tutarlı bir söylem ve anlatı sistemi oluşturması durumunda, her an gerçek olanı oluşturabileceğini söylemek olasıdır. Bunun nedeni sadece dilin kendine içkin değerlerinin olması değil, okurların kabul konusundaki temel arzularıdır. Borges'in söylediklerinden yola çıkarak, anlatıların gerçekliğin insan yapımı olduğunu ve her an onun yerine başka gerçeklikler kurabileceğimizi anlarız.

Sürekli değişen tüketim mallarının, moda, değişim, gelişim, yenilik, farklılık gibi kavramlarla insanlar tarafından tüketilmesi gerekir. Ürünler reklamlar, imgeler, yarışmalar, haber sunumları, televizyon programları vb pek çok popüler kültür aracıllğ 1 ile tüketicilere sunulur. Ancak sunumun tüketimi tetikleyebilmesi için yeni bir ihtiyaç hissinin, düşüncesinin oluşması da gerekir. İhtiyaç düşüncesinin / algısının, farklı dilsel bağlamlar yaratarak oluşturulması mümkündür: "Semantik/politik ve felsefi sorunsalın dışlanışı gibi, duyusalın dışlanışı da kavramsal sanat ürünlerini ister istemez kullan-at sloganinda yetkin ifade biçimini bulan tüketim ekonomisinin mantığına bitişstiriyor" (Oktay, 2000:14). Postmodern romanın da yaptığı şey benzerdir. Temsil ettiği kültür gibi, roman gerçeklikten korktuğumuz, daha iyisi var olduğu ya da yıkıcı sonuçları olduğu için onu değiştirmeye çalışmaz. Yeni gerçeklikler sınırsız bir tüketim olasılığı sunduğu için onların temsiliyet sorunu önemlidir. Sahip olduğu iki inandırıcı ve doğru silah bulundurur: dilin keyfiliği ve söylemin insan tarafından değiştirilebilirliği. Aynı nedenden ötürü, postmodern roman öncül gerçekliğe saldırır ve toplumsal algımızı, doğruları, gerçekleri, ekonomik konumumuzu, kültürel kimliğimizi çarpıttığını ve bu yüzden zararlı olduğunu öğretmeye çalışır. Ancak, nedendir bilinmez, postmodern roman ya da kültür neyi savunmadığının açıklamasını mükemmel derecede yaparken, neyi savunduğunun açıklamasına ise hiç girmez.

Roman dünyası insan tarafından kurgulanan bir dünyadır ve bizim dünyamız gibi, ya da onu anladığımız gibi, düzenli bir sitemle kurgulanmıştır. Olası bir dünya olarak karşımıza çıkar. Roman dünyası ile insanın fiziki dünyasının gerçekliği, ya da 
gerçeklik algısından farklı olarak, insan yapımı, düzenlenmiş, ayıklanmış kapalı anlatım sistemleri yoluyla kurgulanır ve "bu yüzden olası olsa bile, gerçeklik ya da doğrulukla ilişkisizdir" (Borges, 1985:35). O zaman, postmodern roman, ya da roman ve genel anlamda edebiyatta, bizi ilgilendiren şeyin gerçeklik yerine olası dünyalar olması gerekmez mi? Başka bir değişle, roman, bize dünyayı açıklamak, anlatmak, insanları tanıtmak, yerleri, mekanları betimlemek için yazılmaz. Bunları öğrenmek için roman okumayız, ama roman okumanın etkilerinden biri, doğal olarak, bunları da öğrenmektir. Roman, hayatı açıklamak için değil, farklı hayatların olasılığını, bize kurgusal anlamda yaşatmak içindir.

Alternatif yazım tekniklerine dikkat çekerek, postmodern romancılar dilin altında yatan ideolojileri okurun dünyasına sokarlar. Roman ve öykülerde, yeni bakış açıları sunulur. Kendi dünyamızı ve dünya hakkındaki bilgilerimizi sorgulamamız istenir. Dünyanın / yaşamın bir dizi heterojen eylemlerden oluştuğu ve eylemlerin dizili, düzenli, sıralı olmadıkları gösterilmeye çalışılır. Olgular, kavramlar ve olay örgüsünün parçalanmışlı̆̆ sunularak, zihinsel bir işlemin okuru kesin bir yoruma götürmesi engellenir. Sinıflandırmaların, genellemelerin, kesin yargıların önü kesilir. Zamanın bile var olmadığı, sadece göreceli bir kavram olduğu gösterilir. Şimdiki an tanımsızdır, geçmiş sadece şimdiki hafızada yer aldığı kadarıyla gerçektir ve gelecek ise sadece şimdiki anda bir olasılık olarak vardır.

Postmodern roman insanın, gerçeği istila eden, ondan daha güçlü hale gelen olası dünyalar oluşturma yeteneğini ortaya çıkarır. Tarih değişir, felsefi görüşler çürütülebilir ve gerçek sürekli değişerek yeniden insanın önüne konabilir. Temsil yöntemleri ve sistemleri değiştikçe değişmeyecek hiçbir görüş, ideoloji, kavram ya da doğru yoktur. Şair ve yazar, artık karşımıza eski saflığ 1 ve halesi ile çı(a)mamaktadır: "TV'de, radyoda, gazetede, yayınevinde, reklam şirketinde yapımcı, yayımcı, redaktör, sunucu, talk-show'cu, kampanya düzenleyici ve spot yazıcı'dır o. Bu dizgeyle bütünleşme ya da eklenlenme sürecinin sanat işini "tehlikeli ilişkilere" sokabileceği açıktır. Bu eklemlenme dille gerçeklik, özne ile dünya, toplum ile birey arasındaki diyalektik biçimlenmelerin sunuluşuna ve yorumlanışına Pazar ilişkileri sürecine bağıml farklı bir içerik kazandırabilmektedir" (Oktay, 2000:107). Gerçek ancak deneyimdir, sadece insanın zihnindeki bir algıdır ve dil yoluyla dünyanın çarpıtılmış bir imgesini sunar. Postmodern roman, bu açıdan, zaman ve mekan duygusunun değişkenliğine dayanarak evrensel kişileştirmelerden de arındırılır. Sadece bir yazar vardır, herhangi bir kişi gibi geçicidir ve sıradan bir imgedir. Yazarın önemsizleştirmesi, Roland Barthes'in (2009) "metin" ile "eser" arasındaki ayrımına benzer. Eser nesnenin kendisi iken, metin daha önceki metinlerle serbest bir etkileşim halindeki zihnin ürettiği içeriktir. Önceki birçok metnin ürünüdür ve onlardan pek çok izler taşır.

Postmodern roman belirli ideolojileri ve eğilimleri, modernist romandan daha az işlemez. İşlediği bakış açılarının kendisi ideolojiktir. Tek fark, işleme biçimi ile işlediği düşüncelerin evrensel doğrular olduğunu iddia etmemesidir. İnsan hayal gücünün tüm sınırlarında dolaşan bir anlatım tarzı, postmodern romanı niteleyen bir özelliktir. Filmlerin, reklamların, televizyon programlarının ya da dizilerin sunduğu hızla değiş̧en, ilintili ya da ilintisiz pek çok görsel, işitsel imge gibi, postmodern 


\section{Postmodern Roman ve Yeni Dünya Tasarımı}

roman da insan zihnine sürekli değişen dil imgeleri ve bağlamlar sunar. İmgeler bir anda belirir ve hızlıca yerini bir başkasına bırakır. Bir imge okurun zihninde berraklaşacak bir firsat bulamaz. Değişen imgelerin oluşturduğu kişilik tasvirleri de aynı şekilde belirsizdir. Derinlemesine bir kişilik çizilmez. Okur bir dünyadan bir başka dünyaya sürüklenir ve roman kişileri de sürüklenme sırasında aynı kalmazlar. Hem kendileri farklı bağlamlarda farklı davranışlar sergiler, hem ayrı mekanlarda ayrı kişiler ortaya çıkarak anlatımın boyutunu farklı evrenlere taşırlar. McHale (1987) sürekli değişen bu gerçekliğe "hayal gücünün yayılmacıllğ̆ (emperyalizmi)" adını verir. Değişim, yaşamın sürekli devingen anlam dizgelerine benzer. Günümüz toplumunda, bize sunulan haberlerin, reklamların etkisi altında, bir görsel, işitsel bombardıman altında sürekli değiştirilen gerçeklik ve ihtiyaçlar karşısında hiçbir kesinliğe tutunamaz oluruz. Her şey aynı zamanda hem gerçek hem de sanaldır: "yaşamın kendisi bir labirente dönüşmüştür ve olmasl muhtemel olan her şey olabilir, her olasllık kendini var edebilir" (Borges, 1985:11).

Gerçekle kurgu arasındaki sınırlar gizlenmiş ya da bulanıklaşmıştır. Romanın sunduğu gerçekliğin etki açısından günlük yaşantımızda karşılaştığımız olaylardan pek fazla farkı yok gibidir. Postmodern çağda, artık gerçeği sürekli görsel, işitsel imgeler yoluyla algılamaya başlamamızdır. Anlatılar da benzer dilsel imgeler yoluyla bizim algımızı biçimlendirir. Algılama konusunda derinlikten bahsetmek neredeyse imkansız hale gelir. Hız kavramının insan yaşamındaki merkezi konumu gibi, artık ayrıntılar önemsizleşir ve her an yeniyi özleyen, hızla bir şeyleri tüketen, zaman ve mekanda sınırsızı isteyen bir insan tipolojisi ile karşı karşıyayızdır. Postmoden roman, çağa uygun olarak bir roman kişisi geliştirir ve okurun da böylesi bir insan olmasını bekler.

Roland Barthes "metin gösterilenin sınırsız çıkarımların gösterebilir. Gösterense anlamın ilk aşaması olarak düşünülmemelidir” (1977:158) saptamasında bulunur. Postmodern metin ancak dildeki gösteren-gösterilen ilişkisindeki oyunlar haline gelir ve "tüm bildiklerimiz kesin olmayan gösterilenlere dönüşerek bağlantısızlıklar, örtüşmeler ve değişimlere denk düşer" (Barthes, 1977:158). Değişim, kopukluk ve örtüşme hem dilin hem de biçimsel temsillerin sonucudur. Bunun nedeni sadece dilin gösterme işlevi değil, daha önceki metinlerin izlerini okuduğumuz metinde farkında olmadan bulmaktır. Postmodern metin sadece kendi gösterenleri ile işleyen kapalı bir yapıya dönüşür.

Dünyanın değişen yaşam biçimlerine, teknolojik ilerlemelere, ülkelerarası ve ülke içi ekonomik ilişkilere, yeniden şekillenen kültürel değerlere koşut şekilde yaşamı anlatmaya başlayan postmodern romanın genel özellikleri şu şekilde özetlenebilir:

- Geleneksel temsil biçimlerinin kırılması,

- Gerçeklik algısının yok edilmesi,

- Modernist romanın sunduğu değer ve kavramların geçersizleştirilmesi,

- Yeni dünya düzeninin değerlerini dolaylı bir söylemle, üstü örtük şekilde okurun zihnine aktarmas1,

- Popüler kültürü ve tüketim toplumunu kutsamas1, 
- Deneycilik ilkesi doğrultusunda, öncül metinleri içerik, üslup ve biçim açısından taklit etmesi,

- Gösteren-gösterilen ilişkisinin nedensizliğini / keyfiliğini göstererek kurguyu bir oyuna dönüştürmesi,

- Bağlam değiştirme yoluyla, eski kavramlara yönelik algi-kırıcı / yabancılaştırıcı etki yaratması,

- İdeolojisiz dil kullanma iddiasıyla, genelleştirilebilir, ortak, toplumsal ya da ahlaki her türden düşünceden arındırılmış yeni bir ideoloji yaratması,

- İmge yağmuru sunumuyla, kesin anlamlandırma açısından kaygan bir zemin oluşturması,

- Romanı bir deneye dönüştürerek okur, yazar ve anlatı kişilerinin ortak deneyim seviyesine çekilmesi,

- Metinlerarasılık, üstkurmaca, parodi,ironi ve pastiş kullanımı,

- Karikatür düzeyinde, derinliksiz insan tipolojisi yaratmas1,

- Zaman ve mekanla ilgili geleneksel algıyı kırması,

- Merkezsiz bir anlatı oluşturması,

- Düşsel, fantastik ve metafizik öğeleri kurguya dahil etmesi,

- Anlamı ve olay örgüsünü muğlaklaştırma / belirsizleştirmesi,

- Açık uçlu sonlar üretmesi,

- Bütünlüksüz, parçalı, kopuk bir anlatımı benimsemesi,

- Kapsayıcılık ilkesi adına, her türden kavramın, insanın, görüşün ve değerin işlenmesiyle melezleştirilmiş bir metin sunması.

Postmodern romancılar, kurgularında yukarıda açılanan özelliklerden kendi görüşlerine uygun olanı seçerek romanlarını üretir. Dünya değişmektedir ve romancılar da değişime ayak uydurmak için, kültürel, ekonomik, sosyal ve ideolojik açıdan dünyaya eklemlenmektedir. Kendi varlıklarını sürdürmeleri çoğunlukla buna bağlıdır. Kimi romancı, küreselleşmeye karşı bir tavır içine girmeyi tercih ederken, kimisi de yeni oluşumları destekleyen tavır alabilmektedir. Roman bir oyun sahasına dönüşmüştür ve herkese hitap edecek çeşitlilikte kurgu üretilebilir konumdadır. Postmodern anlatılar sınırsız bir hareket alanına sahiptir, ancak içeriğin genelleştirilebilir toplumsal öğelerden arındırılması, romanı toplumsal, düşünsel ve ahlaki işlevlerinden yoksun bırakmıştır.

\section{KAYNAKÇA}

Bakhtin, Michael, (1981). The Dialogic Imagination: Four Essays.(Ed. Michael Holquist. Trans. Caryl Emerson \& Michael Holquist). Austin and London: University of Texas Press.

Barthes, Roland, (1977). Roland Barthes by Roland Barthes, (trans. Richard Howard), New York: Hill \& Wang.

Barthes, Roland, (2009). Yazının Sifir Derecesi-Yeni Eleş̧tirel Denemeler. (İngilizceden Çeviren: Tahsin Yücel), İstanbul: Yapı Kredi Yayınları.

Borges, Jorge Luis, (1985). Fiction. Barcelona: Planeta-Agostini. 


\section{Postmodern Roman ve Yeni Dünya Tasarımı}

Bradbury, Malcolm, (1977). Possibilities: Essays on the State of the Novel. London: Oxford University Press.

Calinescu, Matei, (1987). Five Faces of Modemity. Durham: Duke University Press. Genette, Gerard, (1982). "The Frontiers of Narrative." Figures of Literary Discourse. (Trans. Alan Sheridan. Introd. M.R. Logan), London: Blackwell, pp. 127-44.

Gottdiener, Mark, (2005). Postmodern Göstergeler. (Çeviren: Erdal Cengiz, Hakan Gür), Ankara: İmge Kitabevi Yayınları.

Harvey, David, (2012). Postmodernliğin Durumu. (Çeviren: Sungur Savran), İstanbul: Metis Yayınları.

Hutcheon, Linda, (1984). Narcassistic Narrative. The Metafictional Paradox. London: Methuen.

Hutcheon, Linda, (1989). The Politics of Postmodernism. London: Routledge.

Jameson, Frederic, (1999). Postmodernism, or The Cultural Logic of Late Capitalism. London-New York: Verso.

Johnson, B.S., (1973). Aren't You Rather Young to be Writing Your Memoirs. London: Hutchinson.

Lodge, David, (1977). The Modes of Modern Writing: Metaphor and Metonymy and the Typology of Modern Literature. London: Edward Arnold.

Lucy, Niall, (2003). Postmodern Edebiyat Kuramı. (Çeviren: Aslihan Aksoy), İstanbul: Ayrınt1 Yayınları.

Lyotard, Jean Franchois, (1984). The Postmodem Condition. A Report on Knowledge. (Trans. Geoff. Bennington and Brian Massumi), Manchester: Manchester University Press.

McHale, Brian, (1987). Postmodernist Fiction. New York - London: Methuen. Oktay, Ahmet, (2000). Postmodern Tahayyüle İtirazlar. İstanbul: İnkılap Yayınları. Stevenson, Randall, (1992). Modernist Fiction. An Introduction. Hempstead: Harvester Wheatsheaf. 